\title{
Trust Deeds and Mortgages in California
}

I.

7 HE origin of collateral security has been found by historians in the "forfeit." Where there is little exchange of goods, and that little by barter, no law of contracts and no law of collateral security exists, for none is needed. The development of credit creates the demand for security. Most countries seem to have solved the problem at first by substituting the security for the obligation. The debtor gave the creditor something of value as security. If the debtor satisfied the obligation in accordance with its terms he got back his property, otherwise not. So completely, however, was the security substituted for the original obligation that if the security were destroyed or became depreciated, the loss fell on the creditor. Again, the creditor's title was not absolute, and, therefore, even after default, while he could keep the security indefinitely, he could not, as a rule, dispose of it. As might have been expected, in time the creditors worked out an arrangement more satisfactory to themselves by preserving a right to proceed against the borrower if the security became inadequate, or even to proceed personally against the debtor without regard to the security. The difficulty presented by the lack of title in the creditor was solved by taking an absolute conveyance from the debtor in the first place. This arrangement, so highly satisfactory from the creditor's point of view, was disturbed by custom or positive law in the interest of the debtor class to prevent a forfeiture where the value of the security greatly exceeded the debt. ${ }^{1}$ Various methods for relieving the forfeiture or mitigating its rigors have existed. The modern method of most of the continental codes positively prohibits any transfer of absolute title by way of security. The lender can get nothing more than a security right in the goods, a jus in rem, as it is termed by the Code

1 Prof. Wigmore, The Pledge Idea, 10 Harv. Law Rev. 321, 389, 11 id. 18; Brissaud, History of French Private Iaw, 582-620. 
Napoleon. ${ }^{2}$ This gives the creditor a right to have a sale on default, usually under judicial process, accounting to the debtor for the surplus, if any, with a personal judgment against the debtor for any deficiency. By no device in the original transaction can the creditor get the right to retain the security without a sale.

In England, these results were accomplished in part through the intervention of the court of equity. Forfeiture in England is not so much prevented as relieved against. At law a mortgage has been defined as

"an estate created by a conveyance, absolute in its form, but intended to secure the performance of some act, such as the payment of money and the like, by the grantor or some other person, and to become void if the act is performed agreeably to the terms prescribed at the time of making such conveyance. It is, therefore, an estate defeasible by the performance of a condition subsequent." 3

The court of equity interposed by allowing the mortgagor to redeen even after default, that is, after condition broken. The mortgagee could foreclose this equity of redemption by going into court and getting a decree that unless the mortgagor paid up within a certain time he should lose the right to redeem.

The court of equity also has and exercises the power of ordering a sale of the property where justice requires it. ${ }^{4}$ The sale being the remedy that best accords with the real nature of collateral security it occurred to the creditor to provile for the sale in the original instrument and thus to avoid the necessity of judicial proceedings. The same result was accoinplished by a trust deed, the trustees being empowered to sell on default. Indeed, for a time, it was doubted whether a sale under a mortgage was entirely fair, and it was suggested that the intervention of a trustee who would represent both parties was necessary to make a sale valid. These doubts were resolved, however, in favor of the validity of the power of sale im a mortgage. ${ }^{5}$ For many years such a power has been given in England by statute. So satisfactory is the statutory power

$2 \S 2114$.

3 Washburn, Real Property, 6th ed., § 975.

* Halsbury, Laws of England, vol. 21, p. 274.

5 Jones, Mortgages, 5th ed., § 1765. 
that only in special cases is such power expressly given in the mortgage. ${ }^{6}$

In the United States the English system prevails in many jurisdictions, while in others the mortgage is treated as a mere security or lien for the performance of an act. Both systems work out the same general result. Under the English theory, title passes to the mortgagee at law with an equity of redemption enforced in equity. Under the lien theory, no title passes to the mortgagee, any agreement to the contrary notwithstanding. The latter view is, it will be observed, an attempt to state the substance of what the court of equity has accomplished. It is simple, logical and in accordance with the facts. The substantial rights of the parties are about the same under either theory. For as Lord Redesdale said, "A great part of what is now strict law was formerly considered as equity, and the equitable decisions of this age will undoubtedly be ranked under the strict law of the next." The lien theory states the result; the title theory perpetuates the historical, accidental and arbitrary method by which the rule was achieved. The lien theory is a road constructed scientifically, after careful surveys; the title theory preserves the circuitous route traversed by the original explorers. It constitutes one of the confusing features of our law due to the perpetuation of the dual system of law and equity.

\section{II.}

It is not, however, the purpose of this article to discuss the theory of mortgages, but the differences between a mortgage and a trust deed in California. It must be apparent that whether the title theory or the lien theory be adopted a trust deed and a mortgage will be treated in much the same way. A court of equity, which requires a grantee of the legal title by a deed intended as security for an obligation to deal with it as a security title only, will look precisely in the same way upon a conveyance to trustees for the same purpose. Likewise, a court which holds that no legal title passes to the mortgagee will generally hold that no title passes when the conveyance is made to trustees. ${ }^{8}$ Statements are innumerable that there is no real difference between a trust deed and a mortgage, and

6 Maitland, Equity, 279.

7 Mitford, Equity, 429 , quoted in 10 Mich. Law Rev. 597.

8 Jones, Mortgages, 5 th ed., § 62 . 
this is true, ${ }^{9}$ in general, although points of difference do arise. The trustee is said to hold a fiduciary relation, whereas the mortgagee does not. The trustee must, therefore, be personally present at a sale of the property, and he cannot assign his trust in the absence of an enabling provision in the trust deed. $^{10}$ But these distinctions are unsound. The trustee under a trust deed is in no real sense a fiduciary. $\mathrm{He}$ is usually an agent of the lender of the money and in a rational system could well be dispensed with. The attempt to fasten the strict fiduciary duties of the trustee of an express trust upon the trustee of a security deed is bound to run counter to the expectations of the parties. The trustee of a trust deed for security is in reality no more of a fiduciary than the law compels a mortgagee to be.

While in most jurisdictions there is little difference between a trust deed and a mortgage the courts of California, strangely enough where the lien theory of mortgage has been adopted, have preserved trust deeds in which the legal title actually passes. Both the lien theory and the legal title theory have been made to work fairly well. When, however, the two theories are simultaneously in operation in the same jurisdiction, diffculties are sure to arise. Where there is one and the same object to be accomplished there should be but one method of accomplishing it. Important collateral differences should not be made to depend upon the more or less accidental choice of one security rather than the other.

What are some of the differences between mortgages and trust deeds in California? The lien theory as to mortgages was covered by the Practice Act of $185 \mathrm{I}$, later embodied in the Code of Civil Procedure. ${ }^{11}$ Deeds of trust in which the legal title passed to the trustee were, however, sanctioned in Koch v. Briggs. ${ }^{12}$ This was an action of ejectment by the purchaser under a trustee's sale. The sale in question had no greater effect than a power of sale exercised by a mortgagee under a power in the mortgage with permission in the mortgagee to buy. Yet the court said, in regard to a trust deed,

9 Shillaber v. Robinson (1877), 97 U. S. 68, 24 I. Ed. 967.

10 Jones, Mortgages, 5th ed., \$1862.

11 Cal. Code Civ. Proc., $\$ 744$.

12 (1859), 14 Cal. 256. 
"It has no feature in common with a mortgage, except that it was executed to secure an indebtedness. This will be evident from a consideration of the rights of parties to a mortgage with reference to the mortgaged property. Where there is a mortgage there is a right, after condition broken, to a foreclosure on the part of the mortgagee, and a right of redemption on the part of the mortgagor. It matters not whether we consider the instrument a conveyance of a conditional estate in the land, as at common law, or as creating a mere lien or incumbrance for the purpose of security, as by our law. The right to foreclose,-whether resulting in vesting an absolute title to the property in the mortgagee, as formerly in England, or in a judicial sale of the premises, as in this State,-exists in all cases of mortgage, after breach of condition, as does also the right to redeem the property from forfeiture, or from the incumbrance of the lien. These two rights are mutual and reciprocal. When the one cannot be enforced, the existence of the other is denied, and when either is wanting, the instrument, whatever its resemblance in other respects, is not a mortgage."

To this it may be said that security for an indebtedness is the important and essential thing in the whole transaction. A paramount public policy will not permit the mortgagee in a mortgage to get the legal title, no matter how emphatically the parties may have expressed that intention. It is not a matter on which the parties are competent to contract. Precisely the same reasoning applies to trust deeds, but by putting the transaction in the artificial form of a conveyance of the legal title it becomes necessary to determine in each case as the question arises whether the form of the transaction or the substance is to be given effect. ${ }^{13}$

It is too late to question trust deeds in California. Their validity has been reaffirmed in numerous cases. Even the

${ }^{13}$ Grant v. Burr (1880), 54 Cal. 298; Bateman v. Burr (1881), 57 Cal. 480; Savings and Loan Soc. v. Deering (1885), 66 Cal. 281, 5 Pac. 353; Sacramento Bank v. Alcorn (1898), 121 Cal. 379, 53 Pac. 813. (For the purpose of the revenue system a trust deed has always been regarded as an encumbrance.) Copsey v. Sacramento Bank (1901), 133 Cal. 659, 66 Pac. 7; Sacramento Bank v. Copsey (1901), 133 Cal. 663, 66 Pac. 8, 205. (An action may be maintained for a deficiency after sale. In a mortgage foreclosure the amount of the deficiency may be docketed as a judgment on the return of sale.) Tyler v. Currier (1905), 147 Cal. 31, 81 Pac. 319; United States Oil and Land Co. v. Bell (1915), 219 Fed. 785. It is curious that the opinion in Koch v. Briggs should have been written by Mr. Justice Field. It was Mr. Justice Field who upheld the view that in a mortgage the legal title 
adoption of the code produced no effect, ${ }^{14}$ and the code itself was amended. ${ }^{15}$ Since then attacks have been made on trust deeds as trusts for an unauthorized purpose and restraints on alienation. But the court has held them too strongly entrenched as a rule of property ${ }^{16}$ to be interfered with. As was said in Kinard v. Kaelin, ${ }^{17}$

remained in the mortgagor even at law. In McMillan v. Richards (1858), 9 Cal. $365,70 \mathrm{Am}$. Dec. 655 , there is an intimation that title in a mortgage may pass for some purposes, but there is no such suggestion in Nagle v. Macy (1858), 9 Cal. 426, and in Dutton v. Warschauer (1863), $21 \mathrm{Cal}$. 609, $82 \mathrm{Am}$. Dec. 765 , Mr. Justice Field was willing to go the whole length by holding that no title passed to the mortgagee even in a mortgage executed before the Practice Act, a view to which his colleagues withheld assent, but a view which was later adopted in part at least. Grattan v. Wiggins (1863), 23 Cal. 16; Skinner v. Buck $(1865), 29 \mathrm{Cal}$. 253. The trenchant criticism by $\mathrm{Mr}$. Justice Field of any compromise between the title theory and the lien theory is entirely applicable to trust deeds. "Here the equitable doctrine is carried to its legitimate result. Between the view thus taken and the common law doctrine-that the mortgage is a conveyance of a conditional estate-there is no consistent intermediate ground. In those states where the mortgage is sometimes treated as a conveyance, and at other times as a mere security, there is no uniformity of decision. The cases there exhibit a fluctuation of opinion between equitable and common law views of the subject, and a hesitation by the courts to carry either view to its logical consequences." Goodenow v Ewer (1860), $16 \mathrm{Cal} .461,467$. Yet this same judge perpetuated the inconsistent intermediate ground by upholding trust deeds. In Idaho, a state which adopted all the pertinent sections of the California Civil Code except $\$ \S 2931,2932$, and adopted the code after its provisions had been interpretec in California as sanctioning trust deeds, nevertheless held trust deeds to be mortgages. Brown v. Bryan (1896), 6 Idaho 1, 51 Pac 995.

That a deed absolute intended as a mortgage does not pass the title was early held in California. These decisions were later departed from. The code re-established the earlier rule but the intermediate decisions arose to plague the court for many years. Allen v. Allen (1892), 95 Cal. 184, 27 Pac. 30.

$1+$ "A lien is a charge imposed upon speciflc property, by which it is made security for the performance of an act." Cal. Civ. Code, $\S$ 2872 ; "Every transfer of an interest in property, made only as a security for the performance of another act, is to be deemed a mortgage, except wner $r_{2}$ in the case of Dersonal property it is accompanied by actual change of possession, in which case it is to be deemed a pledge." Cal. Civ. Code, \&2924.

15 The foregoing sections of the code were amended in 1877 by the insertion of the words "other than in trust," and these words were construed to include trust deeds by way of security. Banta v. Wise (1901), 135 Cal. 277, $67 \mathrm{~Pa} .129$.

${ }_{16}$ In Gray, The Rule Against Perpetuities, 2nd ed., $\$ 570$, it is said that trust deeds and mortgages in which the legal title passes should be franlily declared to be an exception to the rule against perpetuities and the Cal:fornia cases on restraints against alienation are cited with approval. Sacramento Bank v. Alcorn (1898), 121 Cal. 379, 53 Pac. 813; Camp v. Land (1898), 122 Cal. 167, 54 Pac. 839; Staacke v. Bell (1899), 125 Cal. 309, 57 Pac. 1012; Atlantic Trust Co. v. Woodbridge Canal \& Irrigation Co. (1897), 86 Fed. 975.

17 (1913), 22 Cal. App. 383. 134 Pac. 370. 
"Finally an attack is made upon the legality of deeds of trust. In this behalf it is urged that the power of sale usually granted in such instruments, and appearing in the deed of trust in controversy here, is voidable and legally nonavailable unless preceded by proceedings to foreclose as in the case of an out and out mortgage. In short, it is the plaintiff's contention that the deed of trust in question must, as a matter of law, be construed and considered as a mortgage with all of the rights, incidents, and obligations thereof, Practically this same point was presented fourteen years ago in the case of Sacramento Bank v. Alcorn, I2I Cal. 379, $53 \mathrm{Pac}$. 8I3, and there finally and definitely decided adversely to the contention made by the plaintiffs here. The decision in that case has never been overruled, modified, or criticised. On the contrary it has since been continually adhered to, and it stands today as the settled law of this jurisdiction."

One of the differences between trust deeds and mortgages in California, to which most attention has been directed is the statutory right of redemption, often mistakenly called an equity of redemption. In a trust deed in California the grantor still retains an equity of redemption. $\mathrm{He}$ can pay up the indebtedness at any time before his equity has been cut off by a sale of the property, and can thus regain the legal title, To the mortgage in California, however, besides this equity of redemption there is attached the statutory right to redeem at any time within a year after the foreclosure sale. ${ }^{18}$ The Practice Act of $185 \mathrm{I}$ provided for redemption from execution sales and the early case of Kent v. Laffan, ${ }^{19}$ without much discussion, held that these provisions also applied to sales under mortgage foreclosures. In McMillan v. Richards, ${ }^{20}$ the court indicated that as an original question this decision was open to question, but the rule as established in Kent v. Laffan had becoine a rule of property not subject to change. It is conceded that no such statutory right exists after a sale under a trust deed. ${ }^{21}$ But

18 Where this right of redemption exists after sale, the mortgagor retains possession; this affords some temporary security to chattel mortgagees who may otherwise be cut out very abruptly. Penryn Co. v. Sherman-Worrell Co. (1904), 142 Cal. 643, 76 Pac. 484; Elliott v. Hudson (1912), 18 Cal. App. 642, 124 Pac. 103.

19 (1852), 2 Cal. 595.

20 (1858), $9 \mathrm{Cal}$. 365. It is general law that statutes providing for redemption from execution sales apply to foreclosure sales. 27 Cyc. 1800.

21 Sacramento Bank v. Alcorn (1898), 121 Cal. 379, 53 Pac. 813; Penryn Co. v. Sherman-Worrell Co. (1904), 142 Cal. 643, 76 Pac. 484. 
suppose there is a sale under a power in a mortgage. ${ }^{22}$ Does the statutory right of redemption exist? The question is raised in Cormerais v. Genella, ${ }^{23}$ where the court in sustaining the right to foreclose a mortgage remarked that if the mortgagee chose the cumulative remedy of a sale under a power, a doubt might arise "whether such right of redemption existed." By way of dictum it has been denied that there is any such right. "The continuance of this power in a mortgage is as inconsistent with the general policy of requiring all forced sales to be subject to redemption as are trust deeds." ${ }^{24}$ This dictum has not been sufficient to allay the doubt, with the result that the power of sale while generally included in a mortgage is seldom resorted to in California. In the early case of Benham v. Rowe, ${ }^{25}$ it was said, "Where a power of sale is contained in a mortgage, and under a sale by virtue of such power, the mortgagee becomes the purchaser, the equity of redemption still attaches to the property in favor of the mortgagor." The mortgage in this case, however, was created prior to the Practice Act of I85I. Clearly, therefore, the provisions for redemption in that act could not be applied to the mortgage in question. So that all the court decided in Benham v. Rowe was that where under a power of sale in a mortgage a purchase is made by the mortgagee, the mortgagor's right of redemption will continue for a reasonable time.

A mortgage, as we have seen, may include a power of sale. ${ }^{26}$ The power is cumulative with the right to foreclose which always exists. In a trust deed the trustee's sale is the normal proceeding on default. Can there be a foreclosure under a

22 Practice Act, 1851, § 260, (later Code Civ. Proc. $\$ 744$ ), provided as follows: "A mortgage of real property shall not be deemed a conveyance, whatever its terms, so as to enable the owner of the mortgage to recover possession of the real property without a foreclosure and sale." It might have been held that this section required a judicial decree of foreclosure, but it was held in Fogarty v. Sawyer (1861), $17 \mathrm{Cal}$. 589, that it was competent for a power of sale to be included in a mortgage, and this rule survived the general abolition of powers in California. Cal. Civ. Code, \$ 858; Estate of Fair (1901), 132 Cal. 523, 557, 60 Pac. 442, 64 Pac. 1000, 80 Am. St. Rep. 70.

23 (1863), 22 Cal. 116.

24 Sacramento Bank v. Alcorn (1898), 121 Cal 379, 53 Pac. 813.

25 (1852), 2 Cal. 387. The weight of authority is to the effect that the statutory right to redeem does not apply to a sale under a power, unless the statute so provides. 27 Cyc. 1803.

28 Supra, n. 22. 
deed of trust? It has been held that there can, in cases where the accounts are unsettled, where the trustee refuses to act, or where some other special reason exists. ${ }^{27}$ The court, taking jurisdiction on these special grounds, then proceeds to settle the entire controversy by ordering a judicial sale, differing in this particular from the English courts, which in such cases usually order the trustee to sell. ${ }^{28}$ In other decisions in California, foreclosure of a trust deed has been permitted without any question being raised as to the propriety of the remedy. ${ }^{29}$ But, in Koch v. Briggs, ${ }^{30}$ it was said,

"In reference to the deed in question, no suit for a foreclosure, as in cases of mortgage in England, would lie, for there could be no forfeiture of the estate to enforce, and of course no equity as against such forfeiture to foreclose. Nor would a suit lie for a foreclosure under our system-that is, for a decree adjudging a sale of the premises and the application of the proceeds to the payment of the debt, as such suit could only be based upon the contract of the parties, and the contract here is only that, upon the happening of a certain event, the trustee shall sell. Equity could not adjudge a sale, as in case of a mortgage, without disregarding the express contract of the parties, and making a new and different one."

The language was dictum in the case, for the decision was simply that a sale under the power was effectual. It was not necessary to decide that foreclosure would not lie. The authority is an English case. ${ }^{31}$ This case holds that the parties having provided for a sale by trustees the court could not make a contract for them by ordering a judicial sale. Apparently, however, if the trust deed had authorized foreclosure the courts would have enforced it. The English cases would, therefore, permit effect to be given to the provision often inserted in trust deeds in California that the deed, at the option of the holder, may be foreclosed as a mortgage, although some doubt is cast upon the efficacy of this provision by the deciscited.

27 Curtin v. Krohn (1906), 4 Cal. App. 131, 87 Pac. 243, and cases

${ }_{28}$ Jones, Mortgages, 5th ed., \& 1775.

29 Odd Fellows' Savings \& Comm. Bank v. Harrigan (1878), 53 Cal. 229; Levy v. Burkle (1887), 2 Cal. Unrep. Cas. 778, 14 Pac. 564. See, also, Powell v. Patison (1893), 100 Cal. 234, 34 Pac. 676. 30 (1859), 14 Cal. 256.

31 Sampson v. Pattison (1842), 1 Hare 533, 66 Eng. Repr. 1143. This case involved a charge on land, rather than a security trust deed. 
ions that the parties by agreement cannot confer jurisdiction on the courts..$^{32}$ In most courts in the United States there is a freer resort to judicial proceedings in trust deeds than in mortgages. ${ }^{33}$ Another question that arises, in case the court does sell under a trust deed, is whether the sale is subject to the statutory right of redemption? It has been held that it is. ${ }^{34}$

It is thus evident that there are still many unsettled questions. A mortgage is ordinarily foreclosed: in a deed of trust the trustee sells. A power of sale may be, and usually is, included in a mortgage, but the mortgage does not in practice, as a rule, contain the provisions usual in trust deeds making a recital of notice, default, etc., conclusive in favor of the purchaser $;^{35}$ consequently, and on account of the doubt as to whether the statutory period of redemption exists, the power of sale under a mortgage is seldom exercised. In a trust deed, on the other hand, there is considerable doubt as to whether foreclosure will be permitted, and, if permitted, whether there is the statutory right of redemption.

The greatest disadvantage in a trust deed as compared with a mortgage is that, while in a mortgage the mortgagor retains possession during the statutory period for redemption, at the end of that time the sheriff can put the purchaser in possession. In a trust deed, on the other hand, although there is no period of redemption, the purchaser has no process for getting possession. If possession is refused, the purchaser must bring ejectment, and, by a resort to obstructive tactics, the recovery of possession is often delayed for a long time. The right to bring a foreclosure proceeding, in which all disputed points may be adjudicated and the sale be made effective to the purchaser is extremely valuable. The doubt as to the availability of this remedy is one reason why many bankers and lawyers prefer a mortgage to a trust deed.

32 Scott v. Hotchkiss (1896), 115 Cal. 89, 47 Pac. 45.

33 Jones, Mortgages, 5th ed, $\$ 1773$, cited in Curtin v. Krohn, supra, n. 27.

34 Levy v. Burkle (1887), 2 Cal. Unrep. Cas. 778, 14 Pac. 564; Odd Fellows' Savings \& Comm. Bank v. Harrigan (1878), 53 Cal. 229, was a case where the decree had become final.

35 Such recitals are not necessary to make the sale valid. Savings \& Loan Soc. v. Deering (1885), $66 \mathrm{Ca}$. 281, 5 Pac. 353. But they are greatly relied on. Mersfelder v. Spring (1903), 139 Cal. 593, 73 Pac. 
There are other practical questions connected with the statutory right to redeem. For reasons considered later it is usual for the mortgagee to purchase at the foreclosure sale. Where the right of redemption exists the mortgagee is compelled to pay the amount of the mortgage and costs, if the property is worth that much, otherwise the mortgagor might sell his right to redeem to a purchaser who by redeeming would take the property from the mortgagee. ${ }^{36}$ Where no right of redemption exists there is apparently nothing to prevent the creditor from buying at his own figure, unless the court should follow the English decisions and permit a redemption even after an absolute sale, a proceeding of the English courts which makes a purchase there under a mortgage sale an extremely hazardous proceeding. ${ }^{37}$

Other differences arise from the effect of section 726 of the Code of Civil Procedure, providing for one form of action for the recovery of a debt secured by mortgage, thus prohibiting an action on the note. In a pledge no such prohibition exists. How about a trust deed? In Powell v. Patison, ${ }^{38}$ an action on a note secured by a deed of trust, it was held that a "personal judgment on a secured debt before the security has been legally exhausted is erroneous." In Hodgkins v. Wright, ${ }^{39}$ it was said by Mr. Justice Temple, "It is not admitted that if the conveyances were expressly trust deeds, given to secure the indebtedness, plaintiff could bring a personal action before she had exhausted the security." These views were elaborately expounded by the same judge in Herbert Kraft Co. v. Bryan in the department opinion. ${ }^{40}$ On rehearing, the court in bank set aside the judgment in department on another ground, but proceeded to discuss the nature of trust deeds, as follows:-

"Respondent contends that this action can be maintained on the promissory note independent of the deed of trust,

452; Continental Bldg. Ass'n v. Light (1907), 6 Cal. App. 684, 92 Pac. 1034; Jose Realty Co. v. Pavlicevich (1913), 164 Cal. 613, 130 Pac. 15.

${ }_{36}$ In Weyant v. Murphy (1889), 78 Cal. 278, 20 Pac. 568, $12 \mathrm{Am}$.

St. Rep. 50, the court relieved a party who had bid less than the amount of the judgment, referring to the bid as a "stupid blunder."

37 Maitland, Equity, 272.

38 (1893), 100 Cal. 236, 34 Pac. 677.

39 (1900), 127 Cal. 688, 60 Pac. 431.

t0 The decision in bank is reported (1903), 140 Cal. 73, 73 Pac. 745. The department opinion is reported as Herbert Craft Co. v. Brian (1902), 6 Cal. Unrep. Cas. 923, 68 Pac. 1020. 
and whether or not the security under that deed had been exhausted, and that therefore it is immaterial whether there was a valid sale to plaintiff, or any sale at all; but under the views above expressed it is not necessary to here determine this question. It may be said, however, that the question is not concluded by the fact that section 726 of the Code of Civil Procedure merely provides that there shall be only one action for a debt secured by mortgage, and that a trust-deed is not a mortgage. Assuming that a trust-deed is not within that section, still there are other considerations to be weighed in determining whether a creditor who has accepted such a deed as security has not contracted to pursue the terms of the deed when he attempts to forcibly collect the debt. In Savings and Loan Society v. Burnett, Io6 Cal. 514, it is said-though perhaps not decided-that the grantor retains the right to a conveyance on payment, 'and to a sale as provided in case of default'; and this right seems to be indicated in other cases. Powell v. Patison, IOO Cal. 236, can hardly be considered authority on the point. When in that case the court said that 'It is well settled by authority in this state that a personal judgment on a secured debt before the security had been legally exhausted, is erroneous,' it must have had in mind security by mortgage, for in all cases cited as authority on the point-Barbieri v. Ramelli, 84 Cal. I54; Crim v. Kessing, 89 Cal. 478; and Biddel v. Brizzolara, 64 Cal. 354-a mortgage only was involved. We have been referred to no other case where it has been directly held that an action cannot be maintained on a secured indebtedness without first exhausting the security, where the security was not a mortgage. On the other hand, it was decided in Ehrlich v. Ewald, $66 \mathrm{Cal}$. 97, that an action could be maintained on an indebtedness secured by a pledge of personal property without first exhausting the security, and in Samuel v. Allen, 98 Cal. 406, that an independent action could be maintained on an indebtedness although the plaintiff had a vendor's lien as security. We have noticed the subject to this extent because it has been elaborately discussed and because what has been said may possibly be of some aid in examining the question hereafter, if it should ever necessarily arise in some future case."

Just what aid this opinion affords one who wants to know the law is not apparent. The question discussed occasionally arises. It is conceded that a debt secured by mortgage is not a cross demand which may be considered as mutually compensated under section 440 of the Code of Civil Procedure, nor is 
such a debt available as a counterclaim. ${ }^{41}$ In Pitzel v. Maier Brewing Company, ${ }^{42}$ the court said that it could not be ascertained from the counterclaim whether the debt was secured by a trust deed or by a mortgage. But the court proceeds as follows:

"Therefore, in order that facts sufficient to constitute a good cause of counterclaim be set up it should have been made to appear that the contract of security was such as to relieve the creditor from the obligation of exhausting his security before pursuing a personal action. As the Supreme Court has intimated in the case of Kraft Co. v. Bryan, r40 Cal. 73, 73 Pac. 745, even though a contract for security of this nature lacks the essentials of a mortgage, still the engagements of the parties may be such as expressed in the terms of their contract-call it trust deed or what not-as to entitle the debtor to insist that the creditor shall first resort to the security in obtaining satisfaction of the debt."

Apparently the answer to the question depends upon the terms of the particular trust deed. This controversy must seem strange to lawyers outside of California, for if any proposition is well established it is that in all notes secured by mortgage the creditor has a choice of remedies, and may, indeed, in some cases pursue all of them.

"So soon as the mortgagor has made default in payment of the mortgage debt, the mortgagee is entitled to pursue any or all of his remedies, subject, as regards the powers of sale and appointing a receiver, to the restrictions imposed by agreement or by statute, according as the powers are express or statutory. Hence the mortgagee can at the same time sue for payment on the covenant to pay principal and interest, for possession of the mortgaged estate, and for foreclosure, and can combine these claims in the same action; and until judgment nisi has been obtained in his foreclosure action he can exercise his power of sale".43

With some limitations, this rule is general in the United States. On principle, however, there is something to be said for the view that the implied understanding of the parties in mortgages and trust deeds is that the security should first be exhausted. If this be considered as the settled rule in California in regard to trust deeds, as it certainly is in regard to

41 Moore v. Gould (1907), 151 Cal. 723, 91 Pac. 616.

42 (1912), 20 Cal. App. 737, 130 Pac. 706; see also Crisman v. Lanterman (1906), 149 Cal. 647, 87 Pac. 89.

43 The Laws of England, vol. 21, p. 244; 27 Cyc. 1515. 
mortgages, little harm can result, for in the case of mortgages, and a fortiori in the case of trust deeds, it is perfectly competent for the parties to insert an express provision that the creditor may have and exercise both remedies. ${ }^{44}$

Closely connected with the foregoing question is that of negotiability. Notes secured by mortgage are clearly non-negotiable, not only by reason of section 726 of the Code of Civil Procedure, but also under sections 3088, 3092 and 3093 of the Civil Code. Under these latter sections a note secured by deed of trust would also be non-negotiable, although it may be possible that by stipulations giving an independent right of action on the note, the latter may be negotiable just as if given in part performance of an executory contract. ${ }^{45}$

In both mortgages and trust deeds possession remains in the debtor in the absence of agreement. He has the right to recover possession by action. ${ }^{46} \mathrm{He}$ may declare a homestead on the property, ${ }^{47}$ and the execution of a trust deed after the declaration of a homestead does not constitute an abandonment thereof under section I243 of the Civil Code. ${ }^{48}$ Like a mortgagor, the grantor under a trust deed may devise and transfer the property. ${ }^{49}$ It is subject to attachment and execution by his creditors as real estate. A trust deed does not constitute the trustee the owner so as to require him to give notice of non-responsibility to avoid liens under the mechanics' lien laws. ${ }^{\text {o }}$ The title of the grantor is not divested so as to take away the estate of inheritance required under the McEnerney Act. ${ }^{51}$ Yet while a trust deed is treated much as a mere lien or incumbrance for the purposes of the McEnerney Act, the mechanics' lien laws, etc., it is neither a lien nor

44 Martin v. Becker (1915), 49 Cal. Dec. 142, 146 Pac. 665.

45 In Smiley v. Watson (1913), 23 Cal. App. 409. 138 Pac. 367, the point was raised by the court.

46 Tyler v. Granger (1874), 48 Cal. 259.

47 King v. Gotz (1886), $70 \mathrm{Cal}$. 236, 11 Pac. 656.

48 MacLeod v. Moran (1908), 153 Cal. 97, 94 Pac. 604.

49 Kennedy v. Nunan (1877), 52 Cal. 326; Brown v. Campbell (1893), $100 \mathrm{Cal}$. 635, 35 Pac. 433, $38 \mathrm{Am}$. St. Rep. 314; Godfrey v. Monroe (1894), $101 \mathrm{Cal}$. 224, 35 Pac. 761.

50 This was decided differently in Fuquay v. Stickney (1871), 41 Ca1. 583; but this case was overruled without mention in Williams $v$. Santa Clara Mining Ass'n (1884), 66 Cal. 193, 5 Pac. 85, and expressly overruled in Hollywood Lumber Co. v. Love (1909), 155 Cal. 270, 100 Pac. 698.

51 Warren Co. v. All Persons (1908), 153 Cal. 771, 96 Pac. 807. 
an incumbrance but a conveyance of the legal title under section 1475 of the Code of Civil Procedure. Therefore, where a homestead has been declared on property, and the homestead is mortgaged, and then the mortgagor dies, the mortgagee must present a claim or lose all rights under the mortgage. No claim need be presented, however, under a trust deed, in order to preserve the trustee's right of sale.52 Again, when the statute of limitations bars a recovery on a note secured by mortgage all rights under the mortgage, either by foreclosure or by an exercise of the power of sale, are lost. In a deed of trust, the legal title in the trustee preserves the security after the personal obligation is at an end. ${ }^{53}$

Most of the decisions and reasoning in the above cases can be harmonized on practical grounds and to a certain extent on theoretical.

The first decisions upholding a trust deed gave them about the same effect as would be given under the English system. Then follow such cases as Powell v. Patison ${ }^{54}$ and the opinions of Mr. Justice Temple, where such expressions as the following are used:

"The passing of the legal title in such cases is mostly ideal. It is deemed to have passed only for the purpose of enabling the trustee to convey a title. In all other respects the title remains in the trustor, and is still the right by which he holds that which is his."

"In effect they [trust deeds] are mortgages with power to sell.",56

52 Weber v. McCleverty (1906), 149 Cal. 316, 86 Pac. 706.

53 Grant v. Burr (1880), 54 Cal. 298; Travelli v. Bowman (1907), $150 \mathrm{Cal} .587,89 \mathrm{Pac}$. 347, where the trust deed was reformed after the note had outlawed. The trust deed has the advantage that the statute of limitations does not run in favor of junior lienors and incumbrancers. That the statute bars the power of sale, see Goldwater v. Hibernia Sav. etc. Soc. (1912), 19 Cal. App. 511, 12 Pac. 861, 126 Pac. 863; Faxon v. All Persons (1913), 166 Cal. 707, 137 Pac. 919.

r4 (1893), $100 \mathrm{Cal} .234,34$ Pac. 676.

55 Herbert Craft Co. v. Brian (1902), 6 Cal. Unrep. Cas. 923, 68 Pac. 1020; in Savings \& Loan Soc. v. Burnett (1894), 4 Cal. Unrep. Cas. 701, 37 Pac. 180, it was said that the trustees were but donees of a power (opinion by Haynes, C.), superseded by opinion in bank (1895), 106 Cal. 514, 39 Pac. 922.

${ }_{56}$ Hodgkins v. Wright (1900), $127 \mathrm{Cal} .688,60 \mathrm{Pac}$. 431. In this case it is said, "Trust deeds, to secure payment of a debt, are an anomaly in our system, and one admittedly inconsistent with the policy of this state in regard to mortgages. It is at least doubtful if they would be now sustained but for a line of decisions made before they were very seriously questioned." 
In the effort to minimize the difference between these two forms of security and reduce the trust deed to a power of sale under a mortgage, $\mathrm{Mr}$. Justice Temple represented a tendency to scrutinize rather critically sales by trustees. The moral effect of his opinions would have been to raise considerable doubt as to the value of this form of security. As we have seen, however, these department opinions were overruled ${ }^{57}$ and the modern line of decisions may be said to rest upon the principle that wherever it is necessary to preserve the security of trust deeds the courts will go as far as the courts in England in giving effect to the passage of the legal title to the trustees. Thus, a sale for more than is due will be upheld. ${ }^{58}$ The statutes of limitations will not bar the title to sell. ${ }^{59}$ Indeed, the courts will go further and give a trustee some of the rights of a mortgagee, as when the trust deed is considered a mere incumbrance under the mechanics' lien law. ${ }^{60}$ In short, full effect will be given to the passage of title when it will result in making the debtor pay his debt or validate the title of a purchaser under the trustee's sale. On the other hand, subject to the right of the trustee to secure the payment of the debt, the grantor of a deed of trust deals as freely with the property as if he were the legal owner; as freely as if no trust deed had been given. The tendency of the court to disregard the legal title wherever it is not necessary for the security of the creditor probably constitutes some departure from the English theory and practice. The conception of a trust is anomalous anyway. According to Maitland the right of a cestui que trust is neither a right in rem nor a right in personam, but something of both.

"But if this be so, why is it that the rights of cestui que trust come to look so very like real proprietary rights, so like ownership, so that we can habitually speak and

57 Supra n. 55.

58 Supra n. 55

59 Supra n. 53. There must also be considered as overruled such cases as Partridge v. Shepard (1886), 71 Cal. 470, 12 Pac. 480, where in an action of ejectment the court held that the defendant rightly offered in evidence a deed of trust that had been given by the plaintiff. Also the intimation to the same effect of two judges in Iarue v. Chase (1870), 1 Cal. Unrep. Cas. 613.

60 Supra n. 50. The early cases were consistent in making the trustee take the burden as well as the benefit of the legal title. 
think of him as the owner of lands and goods? Part of the answer has already been given. As regards (if I may be allowed the phrase) their internal character these equitable rights are treated as analogous to legal rights in lands or goods-I mean as regards duration, transmission, alienation. But the whole answer has not yet been given. We are examining the external side of these rights, asking against whom they are good, and we shall find that even when examined from this point of view they are like, misleading like, jura in rem."'

The mortgagor in England probably has more real proprietary rights than the owner of any equitable interest. But in the last analysis his rights are treated as equitable, as a mere right in personam.

"Put the case that he does sell and does convey to a purchaser, the mortgagor will in all probability be able to get back that land from the purchaser, to redeem it out of the purchaser's hands. But mark these words in all probability.' It is not very likely that this land will come to the hands of a bona fide purchaser for value who has obtained the legal estate without notice of the mortgagor's right to redeem-still this is conceivable, for occasionally men are hardy enough to forge title deedswell in that case we shall find out that the sale and conveyance by the mortgagee who had been given no power of sale is not a nullity-the purchaser, perhaps a subpurchaser, will be able to laugh at the merely equitable rights of the mortgagor." 62

"We often say that, subject to the mortgage, Doe is still tenant in fee simple. But remember what this means. So soon as the day appointed for payment of the money has gone by, Doe's rights are purely equitable rights-in many respects they are like the rights of a cestui que trust -that is to say, they will not hold good against a purchaser who gets the legal estate bona fide for value, and without notice." 63

Put an analogous case in California. A grants to $B$, in trust for $C$ in order to secure payment of a note to $C$. The deed is not recorded. $B$ then forges a deed absolute from $A$ to $B$ and records the same. $B$ then conveys the property to $D$, a bona fide purchaser. Would the courts accept the logical

os Maitland, Equity, 281. 
consequences of the legal title theory and give $D$ the property, or would they hold that a trust deed passes no title to convey, except in subordination to the trust? It is not contended that the law must of necessity accord with formal logic and that a right must be either in rem or in personam. The departure from this logical division, however, by the creation of rights which are neither in rem nor in personam, but something of both, according to the attitude of the particular court, has resulted in much unnecessary confusion. It certainly shows the value of accurate juristic analysis as a foundation for law. ${ }^{64}$ The passage of the legal title is entirely unnecessary for security. The mortgagee is amply protected in California by giving him a lien in place of the legal title. This is a right in rem and not a mere right in personam. ${ }^{65}$ It is seldom that any practical difficulty arises as to the nature of the right, for the recording acts give an opportunity to make a right in rem of almost any instrument affecting the title to or possession of real property. ${ }^{\text {Be }}$

This tendency of the California courts to make the trust deed operative wherever necessary to assist the creditor in the recovery of his debt and inoperative for all other purposes is illustrated by cases where the conveyance is made in trust to the creditor himself. Apparently, such conveyances may be recognized as trust deeds and yet foreclosed as mortgages. ${ }^{67}$ Another interesting line of cases is where A purchases land from $B, C$ advancing the money, taking a note from $A$ and a conveyance from $B$ as security, and executing an agreement to convey to A on payment of the note. Such a transaction is said to partake both of the nature of a mortgage and of a deed of trust. It is a mortgage in that it can be foreclosed; a trust deed in that, while a recovery on the note may be barred by the statute of limitations, the legal title is still effective for the protection of the creditor. ${ }^{68}$

64 Prof. Hohfeld, Fundamental Legal Conceptions as Applied in Judicial Reasoning, 23 Yale Law Journal, 16.

${ }_{65}$ Edgar N. Durfee, Lien or Equitable Theory of Mortgage, 10 Mich. Iraw Rev. 587; The Lien Theory of Mortgage, 11 Mich. Law Rev. 495.

${ }^{66} \mathrm{Ca}$. Civ. Code, $\S \S 1158,1215$.

87 Felton v. Le Breton (1891), 92 Cal. 457, 28 Pac. 490; Mayhall v. Eppinger (1902), 137 Cal. 5, 69 Pac. 489.

68 Campbell v. Freeman (1893), 99 Cal. 546, 34 Pac. 113; Woodard v. Hennegan (1900), 128 Cal. 293, 60 Pac. 769; Meeker v. Shuster (1906), 
A parol trust in a mortgage hàs been sustained.

"The decided cases are clearly to the effect that such an agreement as the one under consideration is valid and binding upon the parties. In this state a mortgage conveys no estate im the land, but is a simple lien upon the property. This being true, a transaction of this kind is not within the provisions of the code that an express trust in lands cannot be created except by an agreement in writing or a parol agreement fully executed. Being but a personal chattel, 'a parol trust may attach to a mortgage that the mortgagee shall hold it in trust for his own benefit, and in part for the benefit of another.' "'69

An agreement by which the trustee of a trust deed agreed to hold the legal title on a parol trust would apparently be void. The grounds of the decision in Tapia v. Demartini seem like fictitious reasoning employed to reach a right result. Whether the mortgagee has the legal title or a mere lien, his right is a right in real property, not personal. The validity of the parol trust in a mortgage rests on other grounds, namely, that the debt is the principal thing and the security the incident. There is no prohibition against declaring a parol trust in the debt, for the debt is personalty, although it carries with it the security. The beneficiary of a trust deed holding a note secured thereby could declare a parol trust in the note which would incidentally carry with it a right to the security. In a way, the creditor has a more easily transferable security under a trust deed than by taking a mortgage. Under a trust deed he can transfer the note and the holder of the note can order the trustee to sell. But the transferee of a note secured by mortgage must record an assignment of the mortgage before asserting his right. ${ }^{0}$

\section{III}

The distinction between trust deeds and mortgages thus affects numerous property and procedural rights. No one can tell what cases will arise in the future where the court must

4 Cal. App. 294, 87 Pac. 1102; Prefumo v. Russell (1906), 148 Cal. 451, 83 Pac. 810; Hooper v. Young (1909), 10 Cal. App. 590, 102 Pac. 950. If there is doubt, the instrument is considered a mortgage, Godfrey v. Monroe (1894), $101 \mathrm{Cal} .224,35$ Pac. 761.

69 Tapia v. Demartini (1888), 77 Cal. 383, 19 Pac. 641.

70 Stockwell v. Barnum (1908), 7 Cal App. 413, 94 Pac. 400. 
again determine whether to give effect to or ignore the legal title in the trustee. The above differences, and others which will doubtless occur to the reader, make the practice of the law interesting by complicating the game and adding to its difficulties. An advantage is given to the industrious and ingenious lawyer. Such artificialities, however, offend against scientific legal theory and their productiveness of litigation should hardly commend them to the business world.

Of the two forms of security, which is the better? Most of the advantages to the creditor lie with the trust deed. Yet there are serious defects in the creditor's rights as well as in the debtor's. The lack of a speedy and easy means for the purchaser to get possession has been mentioned, a difficulty which some have sought to overcome by inserting a provision in the trust deed to the effect that after default and sale the grantor of the trust deed should be deemed a tenant of the purchaser. It hardly seems probable that the courts will sanction such an attempt to get the benefit of the summary proceeding of unlawful detainer where the relation of landlord and tenant does not really exist. From the debtor's point of view the trust deed, and, it may be added, the power of sale in a mortgage, are unfair on account of the possibility of sale on default without adequate notice to the debtor. It may, therefore, be said that the trust deed works to the advantage of tricky loan shark creditors and dishonest debtors. The notice provisions in a trust deed are certainly unfair. As everyone knows the notes secured by mortgage and trust deeds usually run for a short period. The creditor naturally wishes to have the option of calling in his loan in a short time. Usually, however, he chooses to let it run as an investment until the statute of limitations is about to expire. This period, four years in California, is absurdly short, and forces a renewal of the note and mortgage or trust deed at considerable expense when neither the creditor nor the debtor desires it. The dangerous possibility in the trust deed is in the power to sell the debtor's property without his knowledge. The notice provided is usually by publication in a newspaper once or twice a week for three or four weeks. There is not one chance in ten thousand that the debtor will ever see the notice. The time has long since gone by, even in the rural districts, where 
the county newspaper is read by its subscribers from beginning to end. In cities, legal notices are generally published in trade or professional journals and hardly anybody reads them. Notice by publication in newspapers is a meaningless superstition preserved by tradition from a haunting fear that, because the courts have so long accepted this sham notice as due process of law, they would not recognize actual notice when given. The amount of money wasted in the useless publication of notices must be enormous. It surely ought not to be difficult to remedy this defect in trust deeds and power of sale mortgages. Actual notice could be given by registered mail, by recordation, by service in the manner of a summons in a civil action or by some other means adequate, and not too expensive or burdensome.

The popular remedy proposed for this defect in trust deeds is to add a period of redemption after sale. This was the purport of two bills introduced in the Legislature during the session of 19r5,-Assembly Bill number 996, which failed to pass, and Senate Bill number 649, which passed both houses but was pocket vetoed by the Governor. These bills seem objectionable for several reasons. (I) They preserve the distinction between trust deeds and mortgages. In other words, they do not go to the root of the trouble. (2) They add to the differences already existing by providing a time and manner for redemption in trust deeds different from the one year redemption period in mortgages. (3) They adopt from the mortgage its most undesirable feature,-the statutory period of redemption.

It is believed this third objection is sound, although many hold the redemption after sale under mortgage foreclosure to be a most beneficent provision. Reference has been made to the fact that in mortgage sales the property is usually bid in by the mortgagee. Everyone expects him to do it. $\mathrm{He}$ is best able to make the purchase because he has the amount of the mortgage invested in the property already, and can complete the purchase without the necessity of raising the entire price as anyone else would have to do. This advantage, which the mortgagee naturally has, tends to discourage other bidders. But this is not all. After a prospective bidder has gone to the trouble involved in making the purchase,-raised the money and paid for title imsurance, or for a search of the records, and 
legal advice, he finds that he cannot get possession for a year, and may not get the property at all if there is a redemption. The one per cent a month interest on a redemption is no compensation at all, particularly if the redemption takes place in a few weeks. What chance has a real estate agent to interest buyers and negotiate a sale under such conditions. A probate sale is worth considering, and the investing public keeps in close touch. with such sales. But hardly anyone, except the parties concerned, pays any attention to foreclosure sales. They are not attractive propositions. In a trustee's sale under a trust deed, owing to the inadequacy of our legal procedure, the purchaser does not know when he will get the property. In a mortgage foreclosure sale the purchaser knows he cannot get possession for a year, and may not get the property at all, owing to the statutory period of redemption. Under such circumstances, is it any wonder that bankers and real estate men often advise clients to have nothing at all to do with mortgage or trustee sales? This, of course, injures the debtor. The law which was designed to prevent a forfeiture creates one by making a sale impracticable, thus virtually forfeiting the property to the creditor unless the debtor can realize something from a sale or mortgage of the right of redemption, not always an easy thing to do and usually expensive. Such are the consequences flowing from this spurious right.

Instead of creating a right of redemption after a sale under a trust deed, remedial legislation should, (I) abolish security trust deeds by making them all mortgages. (2) It should provide for adequate notice of sale and fix the date of sale sufficiently far distant to enable the mortgagee to redeem or find a purchaser. Make the time one year, if that seems necessary to protect the mortgagor from losing his property in time of panic or other financial stringency. (3) Let the sale, when made, be absolute, in order to attract buyers and secure the best price. (4) Whether the sale should be judicial, as in France and Germany, or without order of court, as in England and most of the states of this country, is a question worth careful consideration. But in either case some expeditious procedure should be provided for putting the purchaser into possession. (5) The statute of limitations on debts secured by mortgage should be enlarged. 
There may be interposed the valid objection that the right of redemption after sale is not alone for the benefit of the mortgagor, but equally for the benefit of the junior lienors and incumbrancers, who should, of course, be protected. Some form of notice could be devised which would be reasonable as to them. Certainly the present system is not encouraging to mortgagees subsequent to a deed of trust or to a power of sale mortgage, if no redemption is permitted after such sale. Their rights can be cut off in a month, virtually without notice. A mortgagee after a trust deed takes a long chance.

The law as it stands preserves the enlightened views of collateral security. The creditor cannot keep the security without putting it up for sale, and accounting for any surplus. At the same time he is protected in his right to a sale and to a deficiency judgment. The difficulties are principally in the machinery that has been adapted for carrying out these purposes.

To the lawyer, legislation on these subjects is not a matter of very great importance. The lawyer has learned the present system and can accommodate himself to a change. It is only in case the practical operation of the present system causes sufficient irritation to overcome the natural conservatism of business men and their very proper unwillingness to alter established forms that any legislation will be demanded. If the business world does desire better laws on this subject, there would not be great difficulty in framing them. There are many good models in operation.

Berkeley, California.

A. M. Kidd. 